\title{
IR spectroscopy coupled with chemometrics used as a simple and rapid method to determine the caffeine content of tea products
}

\author{
Lestyo Wulandari, Diana Hanifiyah Sutipno, Dwi Koko Pratoko \\ Faculty of Pharmacy, The University of Jember, Jember, Indonesia
}

\section{Keywords \\ Caffeine content \\ Chemometrics \\ Fourier-transform infrared \\ Near-infrared \\ Tea (Camellia sinensis)}

\author{
Correspondence \\ Lestyo Wulandari \\ Faculty of Pharmacy \\ The University of Jember \\ Jember 68121 \\ Indonesia \\ lestyowulandari@unej.ac.id
}

\begin{abstract}
Introduction: Tea is a popular beverage that comes from Camellia sinensis. Tea is generally categorised into four types: black tea, oolong tea, green tea, and white tea. These four types are distinguished based on the presence or absence of a fermentation process during their processing. One of the compounds that play a role in providing freshness to tea is caffeine. Aims: The purpose of this study was to determine the caffeine content in the tea samples that are on the market. Methods: This was done using the near-infrared (NIR)-chemometric method and using the TLCDensitometry method as a comparison. Infrared (IR) spectroscopy combined with chemometrics has been developed as a simple method to analyse the caffeine content in a tea sample. IR spectra of tea samples were correlated with caffeine content using chemometrics. Results: In this study, the partial least squares (PLS) model of the NIR model that showed the best calibration with $r$ square was 0.958 , and the root mean squared error of calibration (RMSEC) value was 0.070 . The PLS calibration model of the NIR models was further used to predict the unknown caffeine content in commercial samples. The significance of the caffeine content that had been measured with NIR and TLC-Densitometry was evaluated using a two paired sample t-test. Conclusion: The caffeine content measured with both methods gave no significant difference.
\end{abstract}

\section{Introduction}

The leaves and shoots from tea plants are used to make drinks. There are four types of tea that are distinguished from each other based on their fermentation process. Black tea is fermented, while green tea is not. Oolong tea is made through a partial fermentation process (semi fermentation), and white tea is made by taking the youngest tea leaves, which are immediately evaporated and dried without using a fermentation process first (Hirthe et al., 2007).

Consumption of tea can provide general benefits to reduce fatigue, increase physical endurance and mental alertness, as well as by playing a role in the body's recovery process. People often consume tea for health and beauty purposes. Green tea is a type of tea that can be used for weight loss, and it also inhibits premature ageing (Sudaryat et al., 2015).
Caffeine is a methylated xanthine derivative alkaloid. The safe limit of caffeine consumption, according to BPOM (Indonesian Food and Drug Administration), is 150 $\mathrm{mg} /$ day, which is divided into at least three doses (BPOM, 2003). If caffeine is consumed in the right amount, the body will obtain the benefits. However, if caffeine is consumed excessively, this can trigger heart rate acceleration, feeling nervous or anxious and can even trigger insomnia. Thus, special attention to the levels of caffeine consumed must be taken by people whose bodies are lacking in caffeine tolerance, such as children, adolescents, and pregnant women (Belay et al., 2008).

Based on the side effects that arise if caffeine is consumed excessively, it is important to determine its content within tea products on the market. There are several methods that can be used to determine caffeine content, such as UV-Vis Spectrophotometry (Belay et al., 2008; Hasanah et 
al., 2016; Navarra et al., 2017)), High-Performance Liquid Chromatography (HPLC) (Bae et al., 2015; Cunha et al., 2015; Jiang et al., 2015), and TLC-Densitometry (Ford et al., 2005; Riswanto et al., 2015; Torres et al., 2015; Trianto et al., 2009). These methods have several disadvantages, namely requiring specific solvents and reagents. Researchers are currently being challenged to develop an alternative method, which is both fast and reliable. One method that has the potential to be used is near-infrared (NIR) spectroscopy as it has an easier sample preparation process, which does not involve any additional solvents or reagents (Roman et al., 2011; Shafirany et al., 2018).

The spectrum produced by NIR spectroscopy is quite complex, so it is difficult to interpret. To overcome this problem, a method known as chemometrics is needed. Chemometrics uses statistical and mathematical approaches to find the relationship between spectra data and chemical parameters of substances that are difficult to measure directly. This study aimed to create a calibration model using a NIR-chemometric technique in order to determine caffeine content from commercial tea products.

\section{Methods}

The materials used were commercial tea products (black tea, oolong tea, green tea, and white tea), caffeine standard, methanol, chloroform, and thin-layer chromatography (TLC) plates. The instruments used were a $n^{\circ} 60$ sieve, a chamber, an ultrasonicator, micropipette capillaries, a CAMAG densitometer, a NIR device (Brimrose Luminar 3070), and The Unscrambler X 10.2 software.

\section{Preparation of simulation sample}

The tea sample simulation was divided into a training set and a test set collected from various shops, shopping centres, and traditional markets in Jember, East Java, Indonesia. Twenty tea product simulations were prepared as training sets consisting of three types of tea (black tea, green tea, and oolong tea). Four tea samples were prepared as test sets that consisted of black tea, oolong tea, and white tea, and three samples were used as the real samples. The samples used in the study can be seen in Table I.

\section{Preparation of caffeine standard}

$50 \mathrm{mg}$ and $30 \mathrm{mg}$ of caffeine standard were weighed and then diluted in $25 \mathrm{ml}$ of methanol. The standard caffeine mother solutions had concentrations of $2000 \mu \mathrm{g} / \mathrm{ml}$ and $1200 \mu \mathrm{g} / \mathrm{ml}$, respectively. The $2000 \mu \mathrm{g} / \mathrm{ml}$ stock solution was diluted to concentrations of $500 \mu \mathrm{g} / \mathrm{ml}, 800 \mu \mathrm{g} / \mathrm{ml}$, and $1000 \mu \mathrm{g} / \mathrm{ml}$ with methanol. Meanwhile, the stock solution $(1200 \mu \mathrm{g} / \mathrm{ml})$ was diluted to become $300 \mu \mathrm{g} / \mathrm{ml}$ and $600 \mu \mathrm{g} / \mathrm{ml}$.
Table I: Code names used for the tea samples

\begin{tabular}{|c|c|c|c|c|c|}
\hline No. & Code & $\begin{array}{l}\text { Brand } \\
\text { name of } \\
\text { tea } \\
\text { samples }\end{array}$ & No. & Code & $\begin{array}{l}\text { Tea } \\
\text { samples }\end{array}$ \\
\hline (1) & PC & Poci & (15) & BTG & $\begin{array}{l}\text { Cap } \\
\text { Botol }\end{array}$ \\
\hline (2) & $S R$ & Sariwangi & (16) & SSG & Sosro \\
\hline (3) & SS & Sosro & (17) & JWG & Jawa \\
\hline (4) & $\mathrm{DD}$ & Dandang & (18) & $2 T G$ & 2 Tang \\
\hline (5) & $\mathrm{KJ}$ & $\begin{array}{l}\text { Kepala } \\
\text { Djenggot }\end{array}$ & (19) & XNO & Xiamen \\
\hline (6) & GD & Gardoe & (20) & GLG & $\begin{array}{l}\text { Galan } \\
999\end{array}$ \\
\hline (7) & NG & Naga & (21) & TJ & Tong Tji \\
\hline (8) & $\mathrm{BD}$ & Bandulan & (22) & ZTW & $\begin{array}{l}\text { Zet } \\
\text { White } \\
\text { Tea }\end{array}$ \\
\hline (9) & BT & Cap Botol & (23) & GG & $\begin{array}{l}\text { Galan } \\
999\end{array}$ \\
\hline (10) & PR & Prendjak & (24) & GP & Gopek \\
\hline (11) & SM & Sarimurni & (25) & DD2 & Dandang \\
\hline (12) & SB & $\begin{array}{l}\text { Cap Sepeda } \\
\text { Balap }\end{array}$ & (26) & SS2 & Sosro \\
\hline (13) & CT & Tjatoet & (27) & XOO & Xiamen \\
\hline (14) & IDG & Indomaret & & & \\
\hline
\end{tabular}

\section{Determination of caffeine content by TLC- Densitometry method}

The level of caffeine in the tea samples was determined using the comparison method (TLC Densitometry). The samples weighed $400 \mathrm{mg}$ each, and this process was then replicated three times. The tea sample was diluted into $10 \mathrm{ml}$ of methanol. The sample was inserted into an ultrasonicator and run for 10 minutes. The sample solution was then left to stand for 24 hours in the refrigerator in order to optimise caffeine for extraction and then filtered into the vial using filter paper.

All standard caffeine with sample solutions were put on the TLC plate using a capillary micropipette to measure out $2 \mu \mathrm{l}$. After the spot results were dried, the TLC plate was inserted into the chamber, which had been saturated by the chloroform: methanol (9.5:0.5). After the eluent had reached the limit, the plate was lifted and dried. The stain from eluation was scanned, and the purity of the spectra was produced using CAMAG densitometers. The caffeine content in the tea samples was calculated based on the scanning data. 


\section{Determination of calibration model}

The NIR and Fourier-transform infrared (FTIR) spectra data of the training set samples were analysed quantitatively using partial least squares (PLS), principal component regression (PCR) and support vector regression (SVR) chemometrics through The Unscrambler $X 10.2$ software. Variable $X$ (predictor) is an absorbance value of the infrared spectrum data that was correlated to variable $Y$ (reference), which represented the caffeine value $(\% \mathrm{w} / \mathrm{w})$ that was previously determined using the TLC-densitometry method as a comparison. The r-square value of 0.91 or greater and the smaller root-mean-square error (RMSE) value of the model indicated that the model chosen had the best predictive ability. The best calibration model was then tested by leave-one-out cross-validation (LOOCV) and 2-fold cross-validation (2FCV) techniques. The model was validated by LOOCV by removing a set of sample data from the training set, and the rest of the data were used to create the new model. The 2-FCV was evaluated using the test set as an independent sample.

\section{Application in a commercial sample}

The spectra of commercial tea samples were determined by IR spectroscopy. The selected and validated model was then applied to the real sample. The caffeine content of the TLC-Densitometry method results was compared to the IR spectroscopy prediction of the caffeine sample. The results were then inputted into the SPSS Trial version 23.0 programme for further analysis.

\section{Results and discussion}

Samples were given identities using a code that was adjusted to each tea sample brand. The results of NIR and FTIR spectrum data are shown in Figure 1 . The spectra data of all samples were used as predictors of the calibration model.

\section{Determination of caffeine content by TLC- Densitometry}

The wavelength used to scan the spots on the TLC plate using the densitometer was $277 \mathrm{~nm}$. The caffeine content from each sample was expressed using $\% \mathrm{w} / \mathrm{w}$. The level of $\% \mathrm{w} / \mathrm{w}$ of each tea sample was determined by converting the concentration value of the analyte that appeared in the form of a nanogram unit on the densitometer scan results to the initial weighing and dilution. The caffeine content obtained is displayed in Table II.

Table II: Results of R-square and RMSE values of the NIR model

\begin{tabular}{lcccc}
\hline Model & $\begin{array}{c}\text { R-square } \\
\text { Calibration }\end{array}$ & $\begin{array}{c}\text { R-square } \\
\text { Validation }\end{array}$ & RMSEC & RMSECV \\
\hline PLS & 0.9579 & 0.9579 & 0.0699 & 0.0663 \\
PCR & 0.6219 & 0.6078 & 0.2108 & 0.6054 \\
SVR & 0.5597 & 0.5243 & 0.2300 & 0.2175 \\
\hline
\end{tabular}

\section{Determination and validation of the calibration model}

Three hundred twenty spectrum data values from NIR and 58 spectrum data values from FTIR were analysed quantitatively using chemometrics on the Unscrambler $X 10.2$ software. The spectra were analysed using the PLS, PCR and SVR techniques. The spectrum of the training set sample was correlated with the caffeine concentration for determining the calibration model. Spectra data as the variable y (response) and the value of caffeine content of the results of TLC-Densitometry expressed by $\% \mathrm{w} / \mathrm{w}$ as the variable $\mathrm{x}$ were used to predict the variable y (predictor). The best calibration model was the PLS model using NIR spectra because its $\mathrm{R}^{2}$ and RMSEC values were 0.9579185 and 0.0698975 , respectively (Table II). The calibration model showed a good R-value (above 0.91) (Lengkey et al., 2013) and a good RMSEC value. Thus, if the value gets smaller, it will also produce a better calibration model as it shows predictive results that are the same as or near the actual concentration (Trianto et al., 2009). The slope parameter shows the average increase or decrease in the $Y$ variable for an increase in one variable $X$ (the slope size of a line). If the slope is positive, then the shape of the line will increase to the right, as shown in the results of this study. This value indicates that the PLS model of NIR has formed good regression linearity, which was the actual value, and the predictive value has a close correlation (Lengkey et al., 2013). 

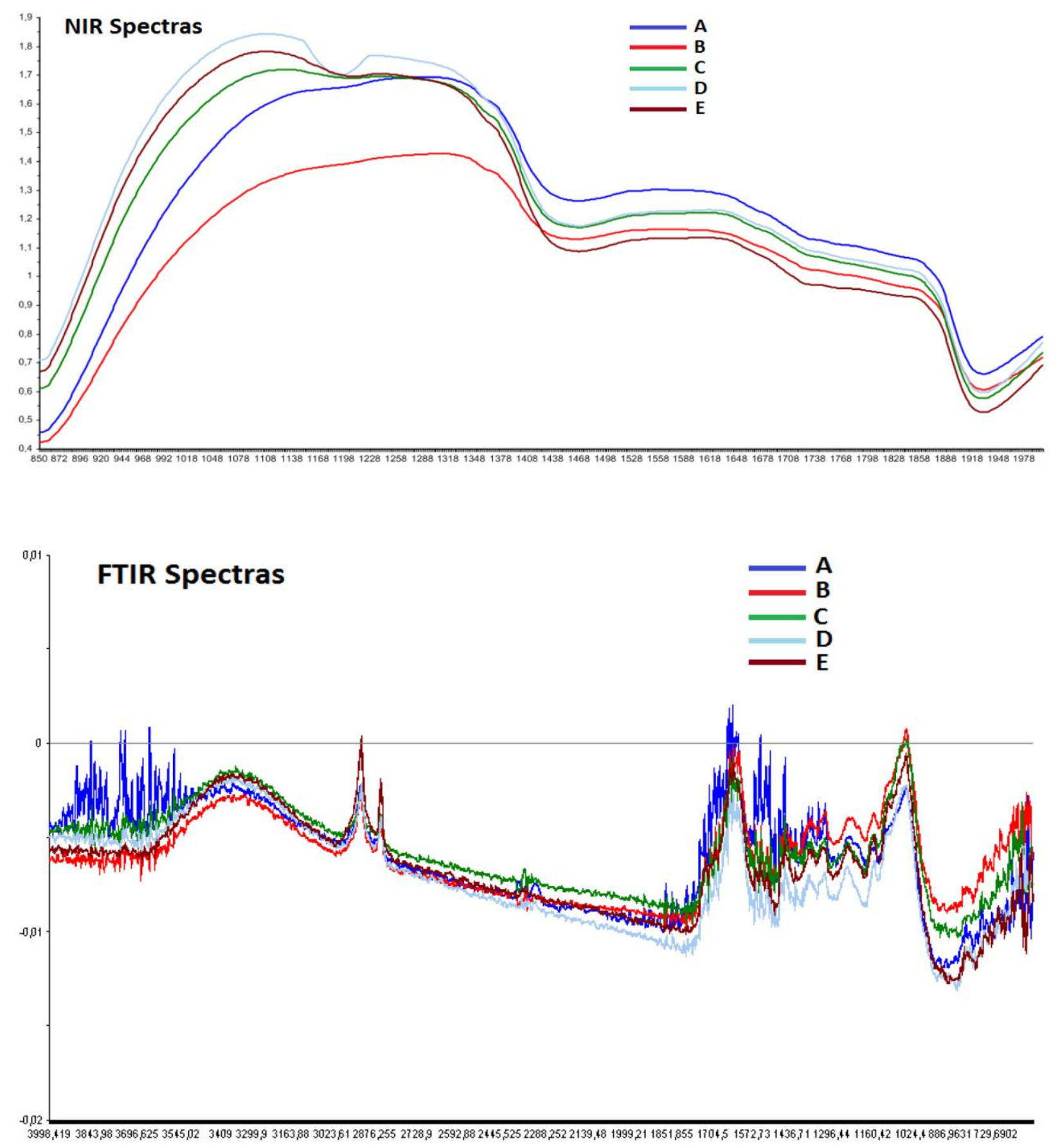

Figure 1: Spectra of NIR and FTIR, identity sample DD (A), KJ(B), PC (C), PR (D), XNO (E)

The calibration model using FTIR spectra had an R2 below 0.91 , so it was the only calibration model using NIR spectra that was further validated. The results of the LOOCV PLS model of NIR showed that the R-square value was greater than 0.91 , and the RMSE values were small ( \pm 0.06$)$ (Table III). Meanwhile, the results of 2-FCV validation through the prediction of the test set sample showed that the R-square and RMSE values obtained were 0.9250847 and 0.0909219 , respectively. Based on the results of LOOCV and 2-FCV validation, it can be concluded that the reliability or consistency of the prediction ability of the PLS calibration model NIR was well-formed, so it can be implemented in the actual sample. 
Table III: Results of LOOCV PLS calibration model NIR

\begin{tabular}{lccc}
\hline Number & Sample leaved & RMSE & R-Square \\
\hline $\mathbf{1}$ & BD & 0.0645 & 0.9486 \\
$\mathbf{2}$ & JWG & 0.0624 & 0.9478 \\
$\mathbf{3}$ & XNO & 0.0679 & 0.9432 \\
$\mathbf{4}$ & SM & 0.0660 & 0.9493 \\
\hline
\end{tabular}

The PLS was validated as the best model calibration and was then applied to the real sample. The real samples that were obtained were scanned using a NIR spectrophotometer, and then the caffeine samples were determined using TLC-Densitometry. The caffeine content of TLC-Densitometry results was compared to the NIR scan caffeine levels by inputting both levels of data into the SPSS trial version 23.0 programme for further analysis. The mean value of $\% \mathrm{w} / \mathrm{w}$ caffeine resulting from the NIR spectroscopy method was compared to the results of the TLC-Densitometry method (Table IV).

Table IV: The comparison results from the NIR spectroscopy and the TLC-Densitometry

\begin{tabular}{lcc}
\hline Sample code & \multicolumn{2}{c}{ Mean value \%bw \pm SD } \\
& NIR spectroscopy & TLC-Densitometry \\
\hline DD2 & $1.28 \pm 0.03$ & $1.33 \pm 0.01$ \\
SS2 & $1.52 \pm 0.02$ & $1.53 \pm 0.03$ \\
XOO & $1.33 \pm 0.09$ & $1.36 \pm 0.03$ \\
\hline
\end{tabular}

Two paired t-test samples were used for the analysis in order to obtain information about whether there was a significant difference between the levels of real samples of NIR scan results with TLC-Densitometry. The results of the analysis of the two paired sample t-test showed that the significance value produced was 0.122 (>0.05), so Ho was accepted. This meant there was no significant difference between the caffeine levels of real samples obtained from NIR and TLC-Densitometry.

\section{Conclusion}

The infrared spectroscopy method in the PLS calibration model of NIR spectroscopy-coupled with the chemometrics method can be used to determine caffeine content. The results of determining the caffeine content in both NIR Spectroscopy and TLCDensitometry methods are the same or have no significant differences. The IR spectroscopy method is rapid, precise, accurate and eco-friendly.

\section{Acknowledgements}

All individuals listed as authors have contributed substantially to the design, performance, analysis, or reporting of the work and are required to indicate their specific contribution. The authors would like to thank the pharmaceutical analysis and chemometrics research group for supporting this research.

\section{References}

Bae, I. K., H. M. Ham, M. H. Jeong, D. H. Kim, dan H. J. Kim. (2015). Simultaneous determination of 15 phenolic compounds and caffeine in teas and mate using RP-HPLC/UV detection: method development and optimisation of extraction process. Food Chemistry. 172:469-475. https://doi.org/10.1016/j.foodchem.2014.09.050

Belay, A., K. Ture, M. Redi, dan A. Asfaw. (2008). Measurement of caffeine in coffee beans with uv/vis spectrometer. Food Chemistry. 108(1):310-315. https://doi.org/10.1016/j.foodchem.2007.10.024

BPOM, Keputusan Kepala Badan Pengawasan Obat dan Makanan Republik Indonesia Nomor. HK.00.05.23.3644 Tahun (2003). Ketentuan Pokok Pengawasan Suplemen Makanan. 9 agustus 2004. Jakarta.

Cunha, R. R., S. C. Chaves, M. M. A. C. Ribeiro, L. M. F. C. Torres, R. A. A. Muñoz, W. T. P. D. Santos, dan E. M. Richter. (2015). Simultaneous determination of caffeine, paracetamol, and ibuprofen in pharmaceutical formulations by high-performance liquid chromatography with UV detection and by capillary electrophoresis with conductivity detection. Journal of Separation Science. 38(10):1657-1662.

\section{https://doi.org/10.1002/issc.201401387}

Ford, M. J., M. A. Deibel, B. A. Tomkins, dan G. J. Van Berkel. (2005). Quantitative thin-layer chromatography/mass spectrometry analysis of caffeine using a surface sampling probe electrospray ionisation tandem mass spectrometry system. Analytical Chemistry. 77(14):4385-4389. https://doi.org/10.1021/ac050488s

Hasanah, U., R. K. Wardani, dan M. A. H. F. Fernanda. (2016). Analisis kadar kafein dari serbuk teh hitam, teh hijau dan teh putih ( camellia sinensis I .). Journal of Pharmacy and Science. 1(1):21-23. https://doi.org/10.53342/pharmasci.v1i1.48

Hirthe, K. (2007). Identification and comparison of phenolic compounds in the preparation of oolong tea manufactured by semi fermentation and drying processes. Agricultural and Food Chemistry. 7462-7468 https://doi.org/10.1021/jf0718603

Jiang, H., U. H. Engelhardt, C. Thräne, B. Maiwald, dan J. Stark. (2015). Determination of flavonol glycosides in green tea, oolong tea and black tea by UHPLC compared to HPLC. Food Chemistry. 183:30-35. https://doi.org/10.1016/i.foodchem.2015.03.024

Lengkey, L. C. E. C., I. W. Budiastra, K. B. Seminar, dan B. S. Purwoko. (2013). Determination of chemical properties in jatropha curcas I. seed IP-3p by partial least-squares regression and near-infrared reflectance spectroscopy. International Journal of Agriculture Innovations and Research. 2(1)

Navarra, G., M. Moschetti, V. Guarrasi, M. R. Mangione, V. Militello, dan M. Leone. (2017). Simultaneous determination of caffeine and chlorogenic acids in green coffee by uv/vis 
spectroscopy. Journal of Chemistry. 2017:8. (7) Harborne, J. B. Metode Fitokimia : Penuntun Cara Modern Menganalisis Tumbuhan; Soediro, K. P. dan I., Ed.; Penerbit ITB: Bandung, 2006. https://doi.org/10.1155/2017/6435086

Riswanto, F. D.O. Lukitaningsih, E. Martono, S. (2015). Analytical method validation and determination of pyridoxine, nicotinamide, and caffeine in energy drinks using TLC-Densitometry. J. Chem., 15 (1), 9 - 15 https://doi.org/10.22146/ijc.21217

Rohman, A., Sismindari, Y. Erwanto, dan Y. B. Che Man. (2011). Analysis of pork adulteration in beef meatball using Fourier transform infrared (FTIR) spectroscopy. Meat Science. 88(1):91-95. https://doi.org/10.1016/j.meatsci.2010.12.007

Shafirany, M.Z., Y. Susilawati, dan I. Musfiroh. (2018). Aplikasi kemometrik dalam penentuan mutu tumbuhan obat. Majalah Farmasi, Sains, Dan Kesehatan. 4(2):6-14. https://doi.org/10.33772/pharmauho.v4i2.6257
Sudaryat, Y., M. Kusmiyati, C. R. Pelangi, dan A. Rustamsyah. (2015). Aktivitas antioksidan seduhan sepuluh jenis mutu teh hitam ( camellia sinensis ( I .) o . kuntze ) indonesia antioxidant activity of ten grades of indonesia black tea. Jurnal Penelitian Teh Dan Kina. 18(2):95-100.

Torres Y Torres, J. L., S. L. Hiley, S. P. Lorimor, J. S. Rhoad, B. D. Caldwell, G. L. Zweerink, dan M. Ducey. (2015). Separation of caffeine from beverages and analysis using thin-layer chromatography and gas chromatography-mass spectrometry. Journal of Chemical Education. 92(5):900-902. https://doi.org/10.1021/ed500977r

Trianto, G. O. (2009). Penetapan kadar kafein dalam teh celup yang beredar di supermarket di wilayah kabupaten jember secara KLT-densitometri. Skripsi. Jember: Fakultas Farmasi Universitas Jember. 